\title{
Black carbon, organic carbon, and co-pollutant emissions and energy efficiency from artisanal brick production in Mexico
}

Miguel Zavala et al.

Correspondence to: Luisa T. Molina (ltmolina@mit.edu, 1tmolina@mce2.org)

The copyright of individual parts of the supplement might differ from the CC BY 4.0 License. 


\section{Supplemental Material}

This Supplemental Material document contains additional information on the instrumentation deployed during the measurement of emissions from the selected brick kilns as well as additional figures and tables that are discussed in the manuscript.

\section{Fuel types and chemical composition}

Table S1 describes the types and amount $(\mathrm{kg})$ of fuels used for the production of bricks in the three kilns sampled. The majority of the fuel used in the three kilns consisted in diverse types of wood. Diesel is used in the Traditional-fixed kiln only at the beginning of the burning stage to initiate the combustion.

Table S2 shows the results of the chemical composition analyses of the fuels used during the burning stages of the brick production process for the MK2 and the traditional-campaign kilns in El Refugio, Guanajuato. The table also shows the heat of combustion of fuels and materials used during the production of bricks. Both of these two kilns are located in the same brick production area and use the same pitch for obtaining the clay for the bricks and use similar types of woods for fuels.

Table S3 shows the results of the chemical composition analyses of the fuels and heat of combustion of materials used during the production of bricks for the traditional-fixed kiln in Abasolo, Guanajuato. The values from these analyses are used in the calculation of fuel, energy and brick-based emission factors following the methods described in the manuscript.

Table S1. Mass [kg] of fuels used during the firing stage of the brick production.

\begin{tabular}{lccc}
\hline \multicolumn{1}{c}{ Fuels } & MK2 kiln & $\begin{array}{c}\text { Traditional-campaign } \\
\text { kiln }\end{array}$ & Traditional-fixed kiln \\
\hline Pine & 294.4 & - & - \\
Indian laurel & 15.5 & - & - \\
Poplar & 83.1 & 165.2 & - \\
Eucalyptus & 259.3 & 107.3 & - \\
Pirul & 350.3 & $1,481.7$ & - \\
Ficus & 171.7 & 22.5 & - \\
Ash tree & 293.1 & 284.9 & - \\
Mesquite & 230.6 & 741.9 & - \\
Manure & 734.4 & $1,568.3$ & $1,784.5$ \\
Avocado wood & - & - & 8.3 \\
Diesel & - & - & $5,930.7$ \\
Sawdust & - & - & \\
\hline
\end{tabular}


Table S2. Chemical composition of fuels and heat of combustion of materials used during the brick production for the MK2 kiln and the traditional-campaign kiln.

\begin{tabular}{lccccc}
\hline \multicolumn{1}{c}{ Sample } & $\boldsymbol{\%} \mathbf{C}$ & $\boldsymbol{\%} \mathbf{H}$ & $\boldsymbol{\%} \mathbf{N}$ & $\begin{array}{c}\text { Mass } \\
(\mathbf{m g})^{\mathbf{a}}\end{array}$ & $\begin{array}{c}\mathbf{H} \\
(\mathbf{M J} / \mathbf{k g})^{\mathbf{b}}\end{array}$ \\
\hline Ash tree & 50.68 & 6.44 & 0.41 & 2.5 & 20.0 \\
Poplar & 50.06 & 6.43 & 0.67 & 2.2 & 18.4 \\
Pirul & 46.22 & 5.99 & 0.28 & 2.5 & 19.3 \\
Pine & 48.74 & 5.35 & 0.66 & 2.2 & 18.9 \\
Indian laurel & 48.69 & 5.75 & 0.43 & 2.5 & 8.1 \\
Ficus & 49.62 & 6.25 & 0.73 & 2.4 & 19.0 \\
Mesquite & 48.81 & 6.19 & 0.39 & 2.5 & 19.5 \\
Eucalyptus & 52.93 & 6.73 & 0.46 & 2.4 & 17.7 \\
Manure & 35.49 & 4.09 & 2.65 & 2.3 & 13.6 \\
Raw brick & 1.28 & 0.64 & 0.19 & 1.9 & - \\
Cooked brick & 0.11 & 0.01 & 0.09 & 2.3 & - \\
Yellow clay & 0.27 & 0.37 & 0.1 & 2.5 & - \\
Black clay & 0.86 & 0.58 & 0.14 & 2.1 & - \\
Ashes & 7.44 & 0.05 & 0.11 & 2.4 & - \\
\hline Mass used & &
\end{tabular}

${ }^{\mathrm{a}}$ Mass used for determining the elemental composition.

${ }^{\mathrm{b}} \mathrm{H}$ : heat of combustion.

${ }^{\mathrm{c}}$ Ashes debris sampled after the burning.

Table S3. Chemical composition of fuels and materials used during the brick production at Abasolo, Guanajuato, for the traditional-fixed kiln.

\begin{tabular}{lccccc}
\hline \multicolumn{1}{c}{ Sample } & $\boldsymbol{\%} \mathbf{C}$ & $\boldsymbol{\% H}$ & $\boldsymbol{\%} \mathbf{N}$ & $\begin{array}{c}\text { Mass } \\
(\mathbf{m g})^{\mathbf{a}}\end{array}$ & $\begin{array}{c}\mathbf{H} \\
(\mathbf{M J} / \mathbf{k g})^{\mathbf{b}}\end{array}$ \\
\hline Avocado & 50.62 & 6.79 & 0.24 & 2.6 & 19.9 \\
Sawdust & 49.86 & 5.25 & 0.41 & 2.4 & 18.6 \\
Diesel & 84.60 & 9.70 & 1.0 & - & 42.9 \\
Raw brick & 0.86 & 0.4 & 0.13 & 2.2 & - \\
Cooked brick & 0.13 & 0.18 & 0.08 & 2.4 & - \\
Yellow clay & 0.24 & 0.33 & 0.13 & 2.2 & - \\
Black clay $_{\text {Ashes }}{ }^{\text {C }}$ & 0.81 & 0.42 & 0.14 & 2.5 & - \\
\hline
\end{tabular}

${ }^{a}$ Mass used for determining the elemental composition.

${ }^{\mathrm{b}} \mathrm{H}$ : heat of combustion.

${ }^{\mathrm{c}}$ Ashes debris sampled after the burning. 


\section{Instruments}

Table S4 shows the characteristics of the instruments deployed for the sampling of brick kilns using the sampling-probe described in the manuscript. Additional peripheral equipment used included filter, probe, hot pump, gas conditioner, distribution lines, gas diluter, temperature controller, flow calibration standards, and autonomous data acquisition system, among others.

Table S4. Characteristics of the instruments deployed for the measurement of emission factors of the kilns using the sampling-probe technique.

\begin{tabular}{|l|l|l|}
\hline \multicolumn{1}{|c|}{ Instrument } & \multicolumn{1}{|c|}{ Pollutants measured } & \multicolumn{1}{c|}{ Specifications } \\
\hline $\begin{array}{l}\text { Fourier-Transfer Infrared } \\
\text { Spectrometer (FTIR) }\end{array}$ & $\mathrm{CO}_{2}, \mathrm{CO}$ & $\begin{array}{l}\text { Gasmet Technologies Oy, model DX } \\
4000 \\
\text { Path length: } 5 \mathrm{~m} \\
\text { Linearity error: < 2\% }\end{array}$ \\
\hline $\begin{array}{l}\text { Flame Ionization Detector } \\
\text { Analyzer (FIDA) }\end{array}$ & Total organic compounds & $\begin{array}{l}\text { California Analytical Instruments, } \\
\text { model 300 HFID } \\
\text { Range: 0 - 300 } \mu \text { mol/mol as } \mathrm{CH}_{4} \\
\text { Linearity error: < 1\% }\end{array}$ \\
\hline $\begin{array}{l}\text { PM } 2.5 \text { Ambient Air } \\
\text { Sampler }\end{array}$ & $\begin{array}{l}\text { BGI Incorporated, model: PQ 200 air } \\
\text { sampler with very sharp cyclone. } \\
\text { Quartz filters were thermally } \\
\text { stabilized and sent to the laboratory } \\
\text { for gravimetric and PM composition } \\
\text { analysis using thermal/optical } \\
\text { analysis. }\end{array}$ \\
\hline
\end{tabular}

Quality control procedures during the sampling-probe technique included:

- Interference Testing Analyzers, prior to first sampling;

- Calibration error test at the beginning of each sampling day of each analyte, in zero, low, middle, and high range concentration levels;

- Bias test for each analyte at the beginning and at the end of each sampling day, using Zero and High-Range calibration gases;

- Drift Test on each analyte at the end of each sampling day, using Zero and High-Range calibration gases;

- Sample interference was maintained at $50^{\circ} \mathrm{C}$ to prevent condensation of water and/or hydrocarbons, as well as to prevent reactions between compounds;

- Sample cell on the FTIR analyzer was heated to $50^{\circ} \mathrm{C}$;

- Use of certified calibration gases with $2 \%$ uncertainty;

- A traceable calibrated gas dilution system (fixed point) was used to deliver different levels of concentration and evaluate the linearity of the analyzer; 
Table S5 shows the instruments deployed by the Aerodyne mobile laboratory (AML), the corresponding pollutants measured, and their associated detection limits for the measurement of emission factors for the three sampled kilns using the tracer ratio technique as described in the manuscript.

Table S5. Characteristics of instruments deployed by the AML.

\begin{tabular}{|c|c|c|}
\hline Instrument & Pollutants measured & Detection limit by pollutant \\
\hline $\begin{array}{l}\text { Tunable Infrared Laser } \\
\text { Differential Absorption } \\
\text { Spectrometers } \\
\text { (TILDAS) }\end{array}$ & $\begin{array}{l}\text { Carbon monoxide }(\mathrm{CO}) \text { and } \\
\text { nitrous oxide }\left(\mathrm{N}_{2} \mathrm{O}\right) \text {; ethane } \\
\left(\mathrm{C}_{2} \mathrm{H}_{6}\right) ; \text { methane isotopes } \\
\left({ }^{13} \mathrm{CH}_{4} \text { and }{ }^{12} \mathrm{CH}_{4}\right) \text {, sulfur } \\
\text { dioxide }\left(\mathrm{SO}_{2}\right) \text {, and acetylene } \\
\left(\mathrm{C}_{2} \mathrm{H}_{2}\right) .\end{array}$ & $\begin{array}{l}\text { Typical detection limits are } 0.1 \mathrm{ppbv} \\
\text { in 1-s, each of the pollutants } \\
\text { quantified in this work is detected in } \\
\text { plume encounters well above the } \\
\text { detection limit. }\end{array}$ \\
\hline $\begin{array}{l}\text { Proton Transfer } \\
\text { Reaction Mass } \\
\text { Spectrometer (PTRMS) }\end{array}$ & Oxygenates, aromatics. & $\begin{array}{l}\text { Typical detection limits are } 0.3-0.8 \\
\text { ppbv depending on compound in } 1-\mathrm{s} \\
\text { of integration time. }\end{array}$ \\
\hline $\begin{array}{l}\text { Soot Particle Aerosol } \\
\text { Mass Spectrometer (SP- } \\
\text { AMS) }\end{array}$ & $\begin{array}{l}70 \mathrm{~nm}-600 \mathrm{~nm} \text { aerodynamic } \\
\text { diameter aerosol, } \\
\text { composition resolved into } \\
\text { black carbon; sulfate; nitrate; } \\
\text { ammonium; chloride and } \\
\text { organic PM. }\end{array}$ & $300 \mathrm{ng} / \mathrm{m}^{3}$ in $1-\mathrm{s}$ integration time. \\
\hline $\begin{array}{l}\text { Thermo Electron } 42 \mathrm{i} \\
\text { chemiluminescent } \\
\text { detector }\end{array}$ & $\mathrm{NO}, \mathrm{NO}_{\mathrm{y}}$ & $\begin{array}{l}0.4 \mathrm{ppbv} \text { in } 1 \text {-s integration time for } \\
\text { each species. }\end{array}$ \\
\hline $\begin{array}{l}\text { LiCor } 6262 \text { Non- } \\
\text { Dispersive Infrared } \\
\text { (NDIR) }\end{array}$ & $\mathrm{CO}_{2}$ & $\begin{array}{l}300 \mathrm{ppb} \text { in } 1 \text {-s integration time. Plume } \\
\text { enhancements in excess } 5 \text { ppm were } \\
\text { quantified. }\end{array}$ \\
\hline
\end{tabular}

\section{Brick-based and energy-based emission factors}

Tables S6 and S7 show the average brick-based emission factors EF ( $\mathrm{g} / \mathrm{kg}$ fuel) and energybased emission factors (g/MJ), respectively, obtained with the sampling probe (SP) and tracer ratio (AML) techniques for the sampled three kilns. The calculations were obtained following the procedures described in the manuscript. 
Table S6. Average brick-based emission factors EF [g/kg-brick] obtained with the sampling probe (SP) and tracer ratio (AML) techniques for the three sampled kilns ${ }^{1}$.

\begin{tabular}{|c|c|c|c|c|c|c|}
\hline & Ml & $\mathrm{K} 2$ & Traditional & -campaign & Traditio & lal-fixed \\
\hline & SP & AML & SP & AML & SP & AML \\
\hline $\mathrm{CO}_{2}$ & $189.4(3)$ & & $192.1(3)$ & & $195.4(5)$ & \\
\hline $\mathrm{CO}$ & $5.32(2.1)$ & $7.83(6.2)$ & $6.36(2.1)$ & $8.21(5.4)$ & $12.33(2.8)$ & $12.34(4.2)$ \\
\hline $\mathrm{TOC}^{2}$ & $0.24(0.3)$ & & $0.63(0.6)$ & & $1.71(0.2)$ & \\
\hline $\mathrm{CH}_{4}$ & & $0.29(0.3)$ & & $0.42(0.4)$ & & $0.69(0.3)$ \\
\hline NO & & $0.12(0.1)$ & & $0.13(0.3)$ & & $0.09(0)$. \\
\hline $\mathrm{NO}_{2}$ & & $0.2(0.2)$ & & $0.12(0.2)$ & & $0.12(0.1)$ \\
\hline $\mathrm{SO}_{2}$ & & $0.12(0.2)$ & & $0.03(0.04)$ & & $0.02(0.01)$ \\
\hline $\mathrm{PM}_{2.5}{ }^{3}$ & $0.23(0.1)$ & $0.2(0.1)$ & $0.58(0.5)$ & $0.29(0.2)$ & $0.16(0.2)$ & $0.15(0.3)$ \\
\hline $\mathrm{BC}$ & $0.02(0.02)$ & $0.08(0.1)$ & $0.03(0.03)$ & $0.09(0.1)$ & $0.06(0.09)$ & $0.12(0.3)$ \\
\hline $\mathrm{OC}$ & $0.003(0.004)$ & $0.062(0.071)$ & $0.038(0.092)$ & $0.148(0.216)$ & $0.016(0.013)$ & $0.021(0.02)$ \\
\hline Fullerene $\left(\times 10^{-3}\right)$ & & $3.7(5)$ & & $3.4(4)$ & & $0.9(1)$ \\
\hline Ammonium $\left(x 10^{-3}\right)$ & $29.5(13)$ & $11.6(8)$ & $118.5(134)$ & $8.4(9)$ & $0.3(0.3)$ & $0.8(1)$ \\
\hline Nitrate $\left(\times 10^{-3}\right)$ & $0.2(0.1)$ & $2.8(4)$ & $1.3(2)$ & $1.6(3)$ & $0.4(0.2)$ & $0.6(1)$ \\
\hline Sulfate $\left(\times 10^{-3}\right)$ & $16.2(12)$ & $14.5(24)$ & $11.6(5)$ & $8.7(13)$ & $5.7(7)$ & $2.5(2)$ \\
\hline Chloride $\left(\mathrm{x} 10^{-3}\right)$ & $73.9(24)$ & 28. (18) & $246.1(264)$ & $28.5(29)$ & $2.5(2)$ & $1.2(1)$ \\
\hline Sodium $\left(\times 10^{-3}\right)$ & $3.3(2)$ & & $2.8(1)$ & & $1.8(1)$ & \\
\hline Magnesium $\left(\times 10^{-3}\right)$ & $0.08(0.04)$ & & $0.17(0.1)$ & & $0.13(0.1)$ & \\
\hline Potassium (x 10-3) & $22.7(17)$ & & $14.4(9)$ & & $5.2(8)$ & \\
\hline Calcium $\left(\times 10^{-3}\right)$ & $0.7(0.5)$ & & 1. (1) & & $0.6(0.4)$ & \\
\hline Fluoride $\left(\mathrm{x} 10^{-3}\right)$ & $0.1(0.1)$ & & $0.3(0.3)$ & & $0.1(0.1)$ & \\
\hline Chloride $\left(\times 10^{-3}\right)$ & $73.9(24)$ & & $246.1(264)$ & & $2.5(2)$ & \\
\hline Bromide $\left(\times 10^{-3}\right)$ & $0.6(0.3)$ & & $3.0(5)$ & & $0.1(0.1)$ & \\
\hline Ethane & & $0.018(0.02)$ & & $0.027(0.02)$ & & $0.052(0.01)$ \\
\hline Methanol & & $0.238(0.24)$ & & $0.15(0.29)$ & & $0.381(0.14)$ \\
\hline Acetonitrile & & $0.028(0.03)$ & & $0.019(0.01)$ & & $0.054(0.02)$ \\
\hline Acetaldehyde & & $0.135(0.15)$ & & $0.068(0.05)$ & & $0.255(0.06)$ \\
\hline Acetone & & $0.153(0.18)$ & & $0.077(0.24)$ & & $0.106(0.04)$ \\
\hline Acetic acid & & $0.316(0.37)$ & & $0.112(0.32)$ & & $0.122(0.09)$ \\
\hline Benzene & & $0.1(0.11)$ & & $0.083(0.08)$ & & $0.059(0.04)$ \\
\hline Toluene & & $0.111(0.09)$ & & $0.053(0.11)$ & & $0.032(0.02)$ \\
\hline C2Benzenes & & $0.121(0.14)$ & & $0.068(0.19)$ & & $0.022(0.02)$ \\
\hline C3Benzenes & & $0.103(0.12)$ & & $0.056(0.16)$ & & $0.015(0.01)$ \\
\hline
\end{tabular}


Table S7. Average energy-based emission factors EF [g/MJ] obtained with the sampling probe (SP) and tracer (AML) techniques for the three sampled kilns ${ }^{1}$.

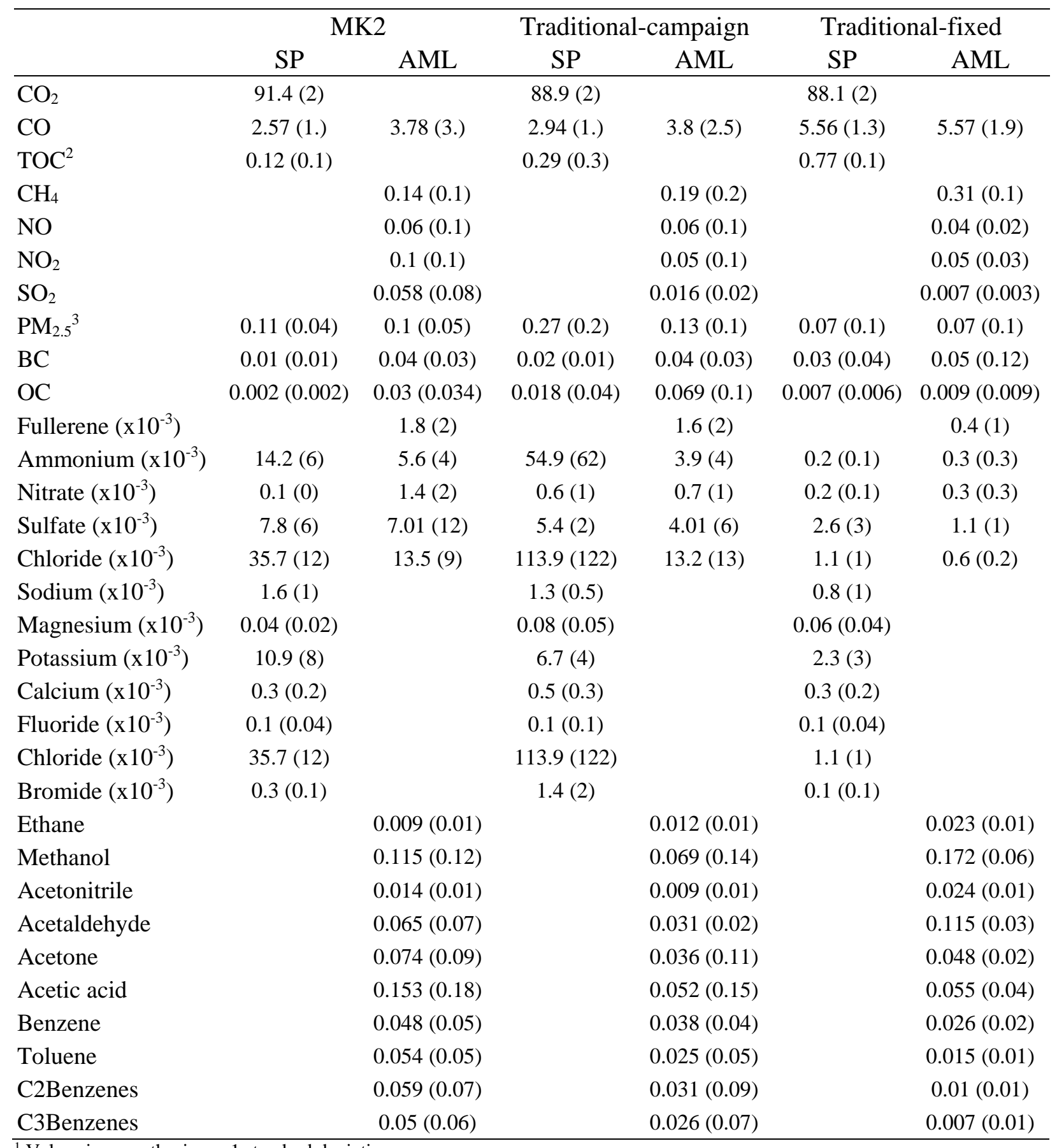

${ }^{1}$ Values in parenthesis are 1 standard deviation.

${ }^{2}$ Total organic carbon measured as methane equivalent.

${ }^{3}$ PM mass and its components from the AML results represent PM in the range 50-600 nm. 


\section{Mechanical resistance of bricks}

Tables S8 shows the average mechanical resistance measured for each of the three levels (bottom, middle and top) for a random sample of 60 bricks at each kiln following the NMX-CC404-ONNCCE-2012 Mexican standard.

Table S8. Mechanical resistance $\left[\mathrm{kg} / \mathrm{cm}^{2}\right]$ of bricks produced.

\begin{tabular}{lccc}
\hline \multicolumn{1}{c}{ Level $^{\mathbf{1}}$} & MK2 kiln & Traditional-campaign kiln & $\begin{array}{c}\text { Traditional-fixed } \\
\text { kiln }\end{array}$ \\
\hline Bottom level & 112.3 & 142.5 & 57.5 \\
Middle level & 98.8 & 138.8 & 78.0 \\
Top level & 78.9 & 118.1 & 87.5 \\
Average & 96.7 & 133.1 & 74.3 \\
\hline
\end{tabular}

${ }^{1}$ Bottom level: $0.4 \mathrm{~m}$ above the combustion chamber; Top level: $0.3 \mathrm{~m}$ below the last layer of bricks at the top of the kiln; Middle level: half the distance between bottom and top levels.

\section{Additional figures}

The following figures are discussed in the text of the manuscript. Figures S1-S3 show the temporal distributions of fuel-based emission factors ( $\mathrm{g} / \mathrm{kg}$-fuel) measured with both the tracer ratio and the sampling probe techniques for the MK2 kiln, the traditional-campaign kiln, and the traditional-fixed kiln, respectively, as described in the manuscript. 

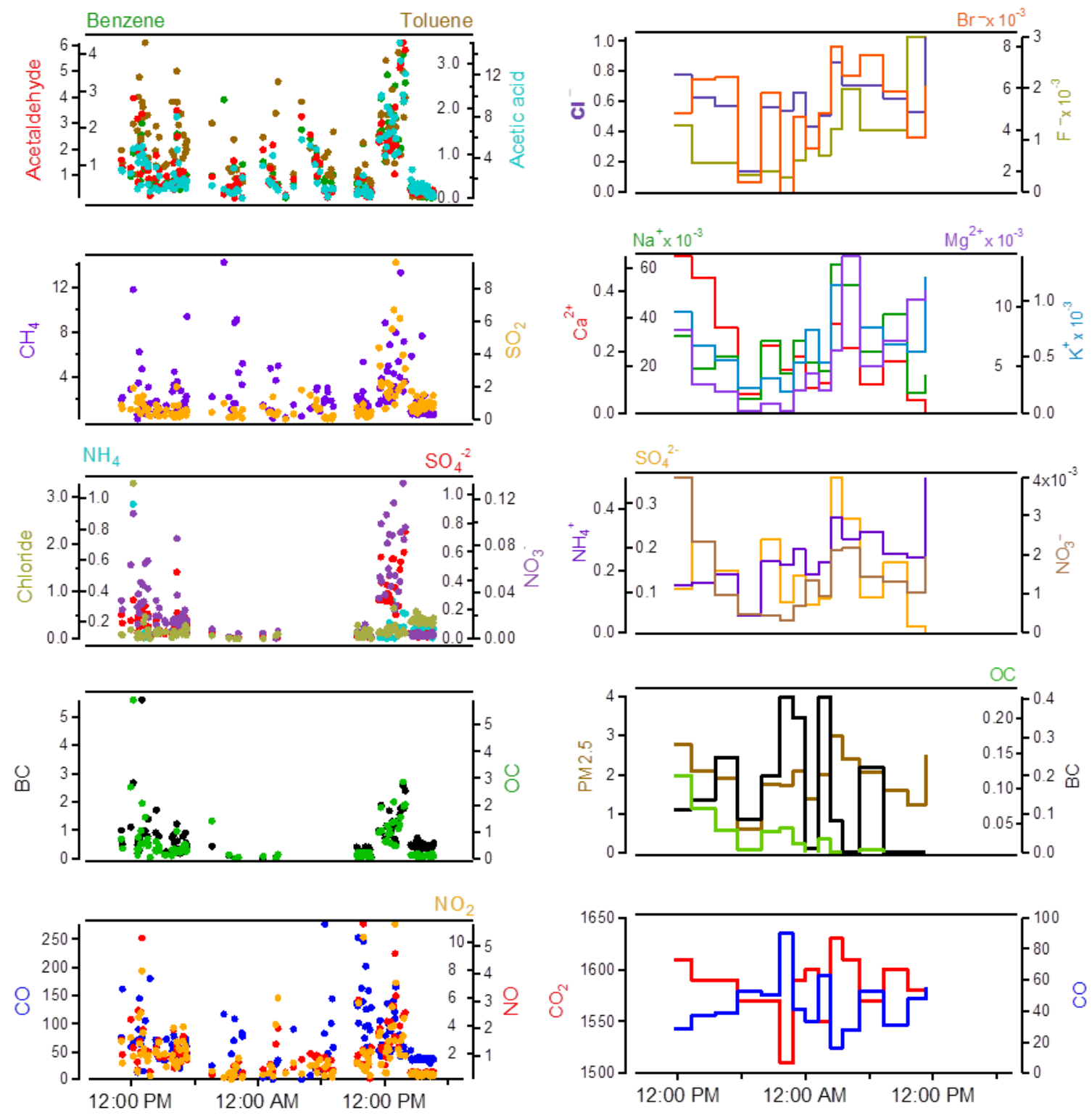

Figure S1. Temporal distributions of fuel-based emission factors (g/kg-fuel) measured with the tracer ratio technique (left panels) and the sampling probe (right panels) techniques for the MK2 kiln. Labels located on the top of the plots correspond to the inner-scaled axis. 

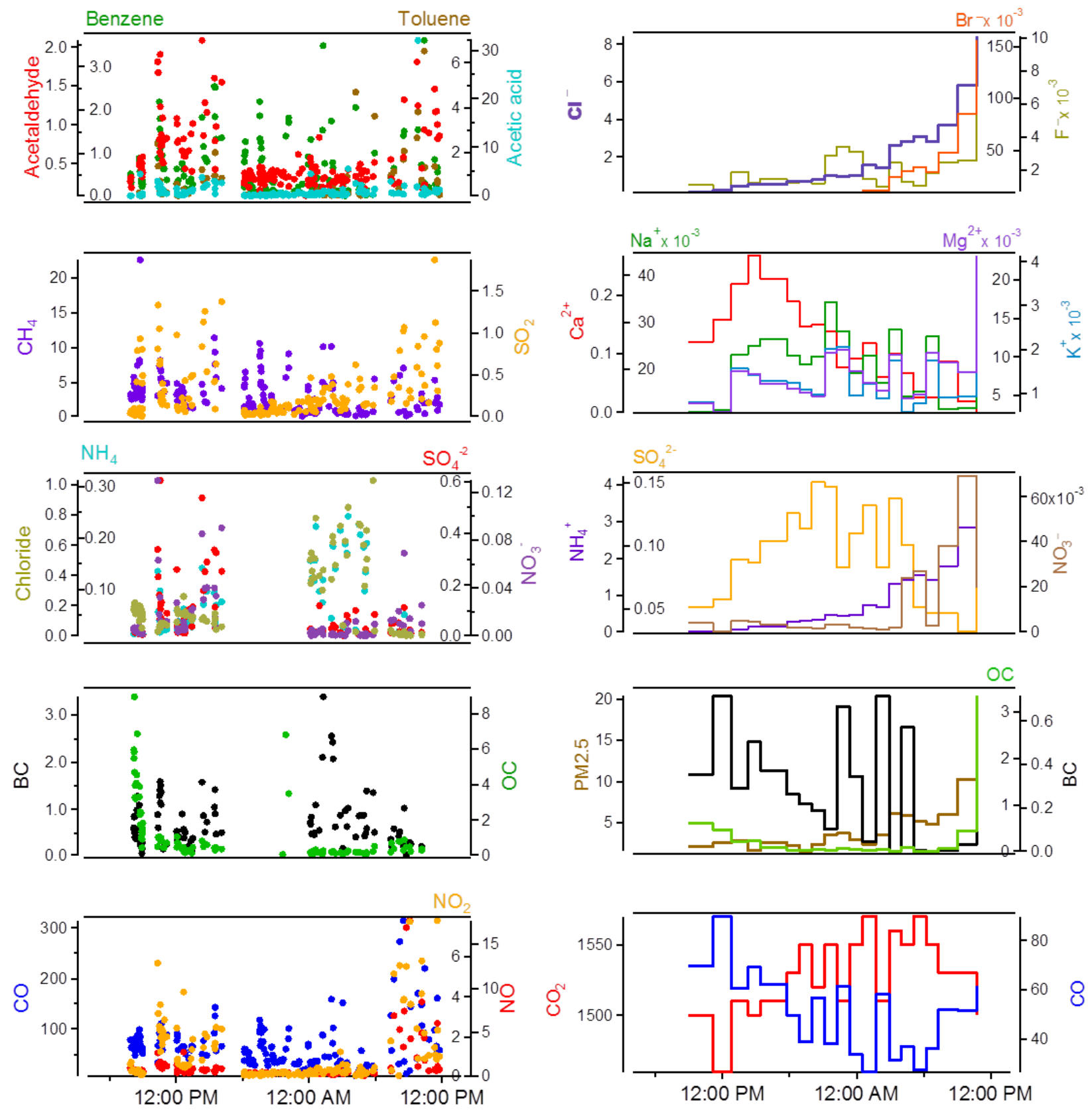

Figure S2. Temporal distributions of fuel-based emission factors ( $\mathrm{g} / \mathrm{kg}$-fuel) measured with the tracer ratio technique (left panels) and the sampling probe (right panels) techniques for the Traditional-campaign kiln. Labels located on the top of the plots correspond to the inner-scaled axis. 

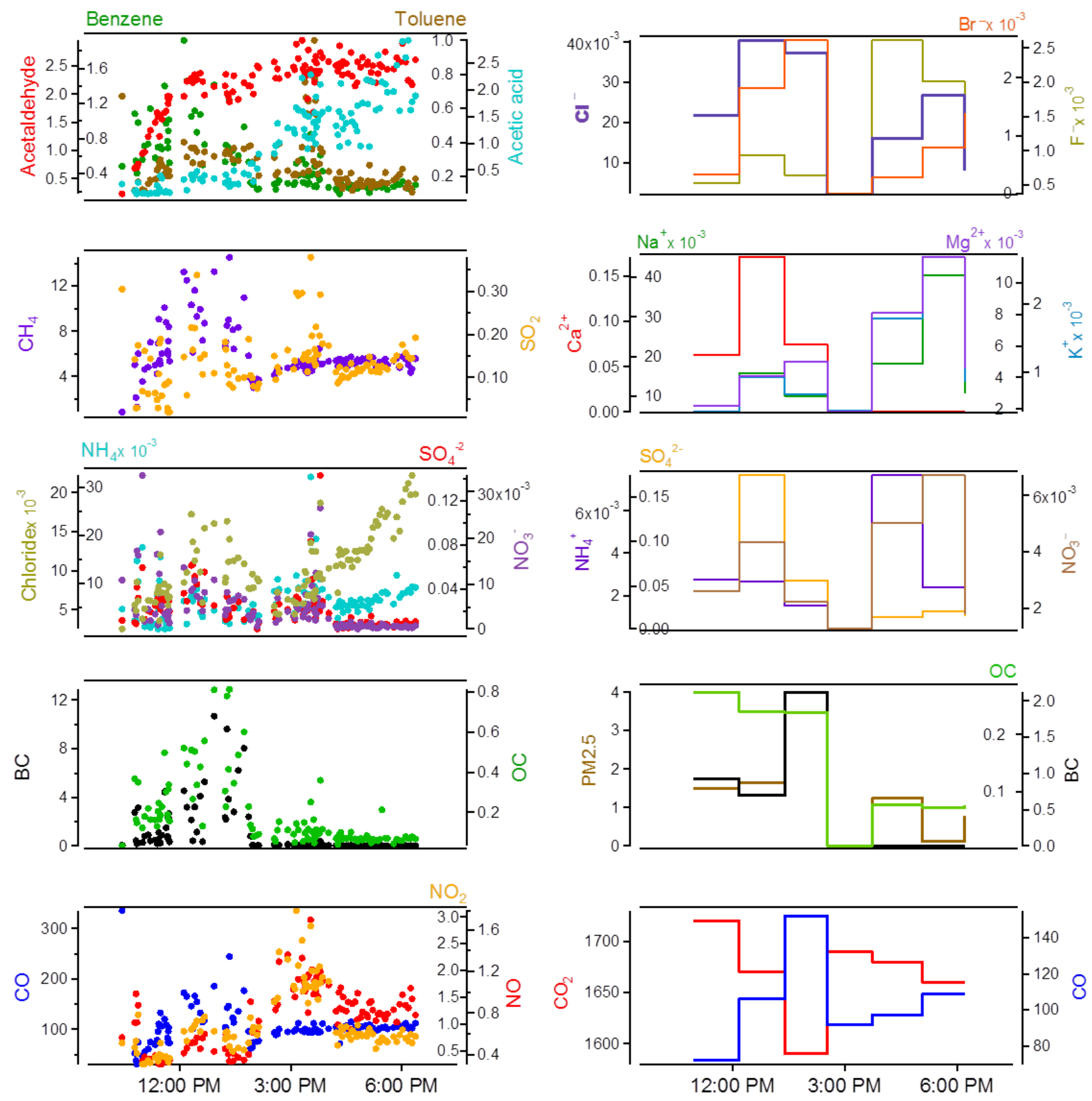

Figure S3. Temporal distributions of fuel-based emission factors (g/kg-fuel) measured with the tracer technique (left panels) and the sampling probe (right panels) techniques for the Traditional-fixed kiln. Labels located on the top of the plots correspond to the inner-scaled axis. 


\section{Kilns sampled and brick production process}

\section{Kilns sampled}

Figure 1 in the main text shows the kilns sampled. The tracers used during the samplings were released close to the top of the kilns so that the tracers mixed with the emissions as they dispersed downwind. Figure $\mathrm{S} 4$ shows the location of the sampled kilns along with the sampling locations for the Aerodyne Mobile Lab as it moved downwind of the kilns depending on the prevailing wind. The figure shows the spatial scale for the samplings using the tracer ratio technique.
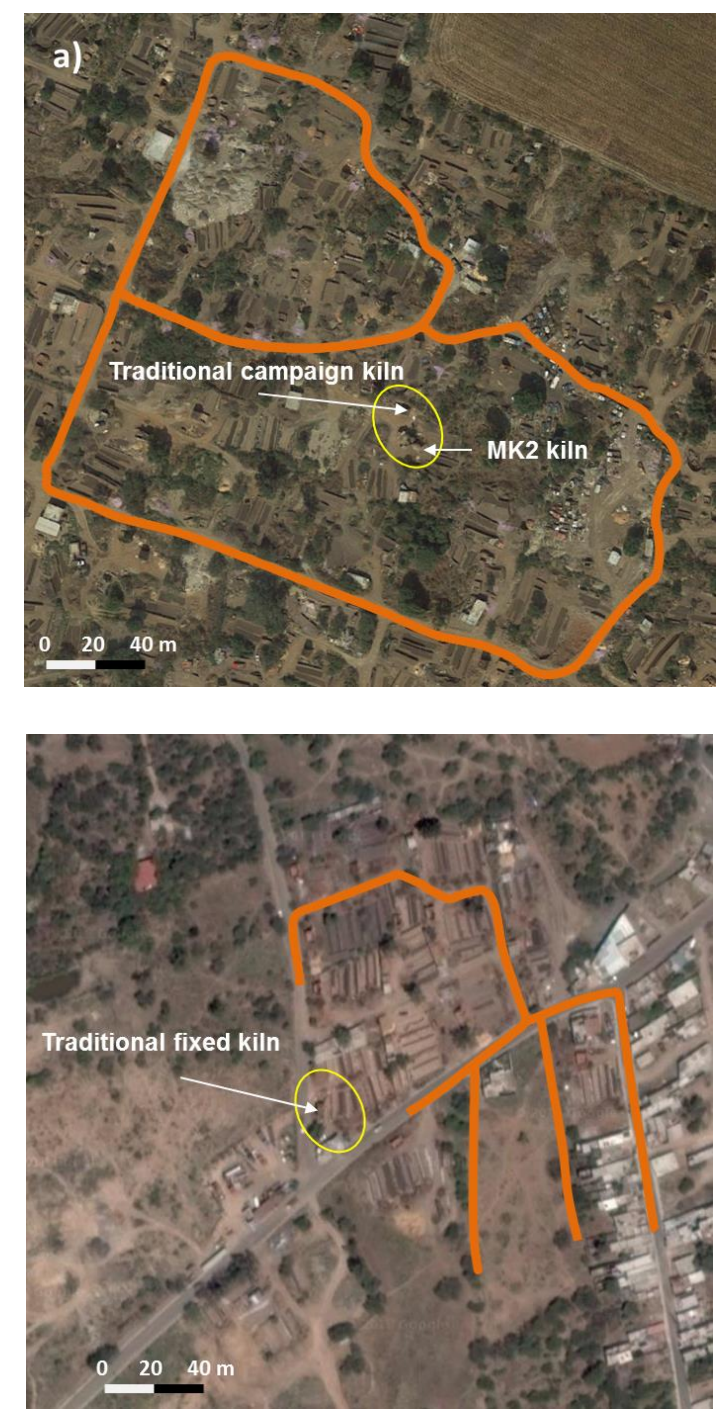

Figure S4. Locations of the sampled brick kilns: a) Traditional campaign and MK2 kilns in El Refugio, Guanajuato, Mexico, b) Traditional fixed kiln in Abasolo, Guanajuato, Mexico. Orange lines represent the sampling locations for the Aerodyne Mobile Lab using the tracer ratio sampling technique as it moved downwind the kiln depending on the prevailing wind advection patterns. 
Traditional-campaign kilns are built with the bricks to be cooked and the sides of the formed kiln were sealed with clay to reduce heating losses. Bricks are arranged internally in a way to form the combustion chamber at the bottom of the kiln and subsequently in a gridded form to allow releasing the exhaust fumes at the top of the kiln. They are called campaign kilns because they can be built in different locations and with varied batch sizes, as needed by the kiln operator. In contrast, traditional-fixed kilns have already built-in walls and combustion chambers and thus are permanently stationed and the batch size is also fixed. Typically, special care is taken to cover any leaks along the walls of the kiln, and the arrangement of the bricks inside the kiln is also designed to force the combustion gases upward through the interior and minimize heating loses.

The MK2 is a relatively new design of "stationary" or fixed kiln in Mexico. The MK2 kiln is a double dome version of the original Marquez Kiln (MK) and involves covering the kiln with a dome and channeling the output flow through a second loaded kiln for its additional filtration of the effluents. Thus, in the MK2 an active kiln is connected at the base with a second identical loaded kiln that effectively acts as a filter of the combustion products while drying the raw material. The batch size depends on the size of the two connected kilns. However, many parameters are involved in a semi-controlled burning process, making it difficult to standardize the kiln design and thus there may be important differences in the resulting energy efficiency. Therefore, MK2 kilns should be carefully designed and properly operated to obtain environmental and energy efficiency benefits.

\section{Brick production process}

As shown in Figure S5, the general steps of brick production include: 1) clay preparation, 2) molding, 3) drying, 4) firing, and 5) unloading. The firing process itself is divided into burning, smoldering, and cooling stages. During the first preparation step a sufficiently large area close to the kiln is cleared from debris and compacted, clay is removed from the soil (usually from a nearby source) and moved close to the kiln site. The clay is then mixed with water and other additives. Tables S2 and S3 show the chemical composition of fuels and heat of combustion of materials used for the MK2 kiln, the traditional-campaign kiln, and the traditional-fixed kiln. The traditional-campaign and the MK2 kilns used about $3.5 \mathrm{wt} . \%$ of manure whereas the traditionalfixed kiln used $8 \mathrm{wt} \%$ of sawdust (see Table 1 in manuscript) as additives. However, in general the brick producer empirically decides the proportions of clay and additives to be used. As described in the manuscript, these organic additives effectively act as internal fuel during the brick cooking process and affect the quality and mechanical condition of the bricks. 


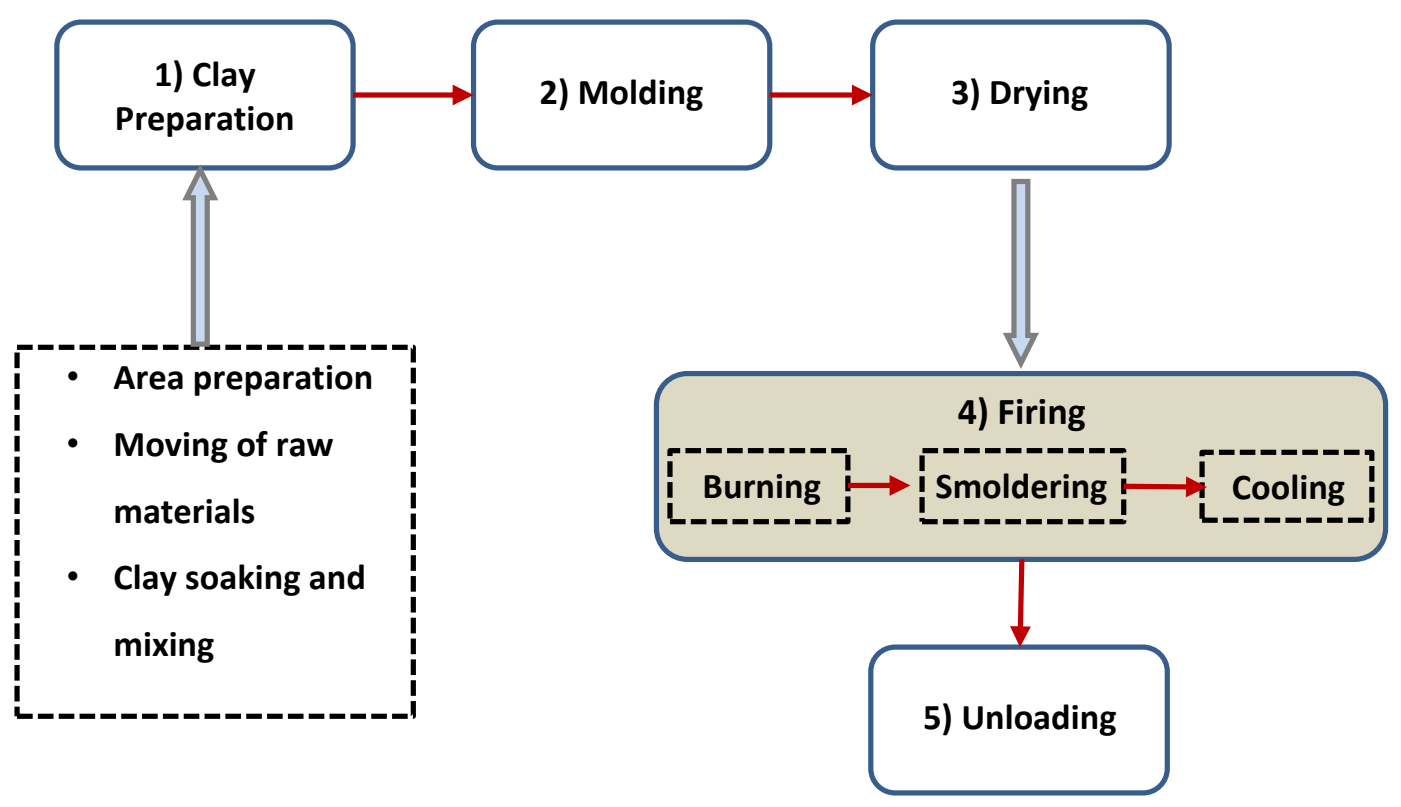

Figure S5. Artisanal brick production process.

The next step involves shaping the mixed clay into brick forms using metal-coated wooden moldings and extruders. The molded bricks are laid out on the previously cleared area close to the kiln and vertically stacked in a latticework frame. This configuration contributes to enhance ventilation through the arrangement and helps to the drying of the bricks, which can take several days. Once the brick producer empirically determines when the molded bricks are sufficiently dried, the bricks are moved to the kiln to be cooked. The bricks inside the kiln are also arranged in a latticework frame to allow an efficient distribution of thermal energy. As discussed in the manuscript, the internal arrangement of bricks together with the design of the kiln determine the rate of vertical transfer of thermal energy, and have large impact on the mechanical resistance and quality of the final product.

Before the firing, the kiln is sealed on the outside wherever is needed using wet soil to minimize transfer of thermal energy to the exterior. The firing step starts by preparing a lower combustion camera or "kitchen" with the needed fuels. Once the firing begins, the process is empirically controlled by the brick producer by supplying the fuels through the combustion camera. Table S1 shows the fuels used during the firing step for each of the three sampled kilns. The stages of burning, smoldering and cooling during the firing step are described in detail in the manuscript. Overall, the duration of these stages is closely related to the efficiency of the vitrification process of the clay and to the final quality of the product. The last step in the process is the unloading of the bricks from the kiln. This last step is done after the kiln is cool enough for the laborers to get inside and manually remove the bricks. Eventually, the piled bricks are transported for commercialization. 